\title{
Financial Literacy as a Driver of Financial Inclusion in Kenya and Tanzania
}

\author{
Ashenafi Fanta ${ }^{1, *}$ and Kingstone Mutsonziwa ${ }^{2}$ \\ 1 University of Stellenbosch Business School, Stellenbosch University, Cape Town 7530, South Africa \\ 2 FinMark Trust, Johannesburg 1632, South Africa; KingstoneM@finmark.org.za \\ * Correspondence: ashenafi@sun.ac.za; Tel.: +27-21-918-4137
}

check for

updates

Citation: Fanta, Ashenafi, and Kingstone Mutsonziwa. 2021. Financial Literacy as a Driver of Financial Inclusion in Kenya and Tanzania. Journal of Risk and Financial Management 14: 561. https://doi.org/ $10.3390 /$ jrfm14110561

Academic Editors: Ştefan

Cristian Gherghina and

Krishna Reddy

Received: 2 July 2021

Accepted: 1 November 2021

Published: 22 November 2021

Publisher's Note: MDPI stays neutral with regard to jurisdictional claims in published maps and institutional affiliations.

Copyright: (c) 2021 by the authors. Licensee MDPI, Basel, Switzerland. This article is an open access article distributed under the terms and conditions of the Creative Commons Attribution (CC BY) license (https:/ / creativecommons.org/licenses/by/ $4.0 /)$.

\begin{abstract}
Efforts are being exerted in many developing countries to promote financial inclusion by increasing individuals' access to financial products and services. However, literature suggests that increasing the supply of financial products and services per se may not help in expanding financial inclusion unless concerted efforts are exerted in enhancing financial literacy. This is because financially literate individuals are more likely to appreciate the value of financial services and hence take up financial products. This paper reports the link between financial literacy and inclusion using data from a demand side financial inclusion survey conducted in Kenya and Tanzania in 2016 covering a total of 6029 individuals. Results from our instrumental variable regression analysis confirmed that financial literacy is a strong driver of financial inclusion. This implies that efforts to promote financial inclusion need to be accompanied with financial literacy campaigns in both countries.
\end{abstract}

Keywords: East Africa; instrumental variable; financial knowledge; financial behaviour

\section{Introduction}

Financial literacy encompasses awareness, knowledge, skills, attitudes and behaviours necessary to make rational financial decision with the ultimate goal of achieving financial well-being (OECD-INFE 2012). Globally, financial literacy is low as only 33\% of individuals show understanding of basic financial concepts (Klapper et al. 2015) and around 3.5 billion individuals in the world are financially illiterate. This is alarmingly high compared to 2 billion unbanked individuals worldwide, which implies that 1.5 billion banked individuals in the world might be financially illiterate. In fact, widespread illiteracy is a concern not only in developing countries but many households in developed countries such as the US are unfamiliar with even the most basic economic concepts needed to make saving and investment decisions (Lusardi and Mitchell 2011). However, literacy levels are particularly low in developing countries as evidenced by a global financial literacy survey where only $32 \%$ of people in sub-Saharan Africa are reported to be financially literate compared to $52 \%$ in high-income OECD economies.

Why does financial literacy matter? Financial literacy is important because financially illiterate people (1) incur higher financial costs and assume higher debts (Lusardi and Tufano 2015), (2) are exposed to exploitation by devious financial service providers (Lusardi and Mitchell 2011), (3) are less likely to seek investment advice and as a result more likely to make investment mistakes (Von Gaudecker 2015) and (4) are more likely to report credit arrears or experience difficulty paying their debts (Disney and Gathergood 2011).

Financial literacy affects people's choice of financial products in such a way that financially literate individuals are more likely to seek and use relevant information, and also make better use of information (Lührmann et al. 2015; Burke and Manz 2014). Financially literate people are also more likely to look for advice from financial advisers and are also more likely to get useful advice (Calcagno and Monticone 2015). They are also more likely to take up financial products such as a bank account or a loan (Cole et al. 2011), accumulate enough stock of wealth for use upon retirement (Jappelli and Padula 2013), participate 
in financial markets (Klapper et al. 2013; Acquah-Sam and Salami 2013), successfully run their small businesses (Dahmen and Rodríguez 2014), set aside funds for a rainy day and use several sources of information when choosing financial products (Silgoner et al. 2015). Financial literacy is also important for macroeconomic stability as evidenced by a study in Russia where financially literate people were able to withstand income shocks and reported higher spending capability which is important for macroeconomic stability during a financial crisis (Klapper et al. 2013). In general, financial literacy is important in both developed and developing countries, albeit with different emphasis.

In developed countries, financial literacy is viewed as a tool for empowering consumers and to complement consumer protection (Xu and Zia 2012). Recently, the dynamism in the financial sector of developed countries reinforced the need to promote financial literacy. Besides, rapid financial innovation that led to the emergence of complex financial products, such as mortgage-backed securities, requires an adequate degree of financial literacy to make rational financing or investment decisions, whereas developing countries put emphasis on encouraging participation of households in financial markets to increase product uptake. In each case, the ultimate goal of financial literacy is to enable individuals to understand key financial concepts and develop the skill to manage their finances to lead a financially healthy life.

In developed countries, financial literacy data is collected to gauge the level of financial literacy across population groups as well as to examine efficacy of financial education programs in improving financial literacy. One such attempts is the OECD's financial literacy survey piloted in 2013 in 14 countries across four continents. However, unavailability of data on financial literacy in Africa led to paucity of studies on its causes and consequences in the African context. Therefore, this study was conducted with the aim to examine the link between financial literacy and financial inclusion in Kenya and Tanzania, lower middle-income economies in East Africa.

To understand the link between financial literacy and socio-demographic factors, we examine determinants of financial literacy following previous studies that report age, gender, income and level of education (Finke et al. 2016; Xu and Zia 2012; Klapper et al. 2015) as determinants. The effect of age on financial literacy is described by Finke et al. (2016) who reported that young individuals are less financially literate due to limited financial responsibility, and literacy increases at later ages but starts to decline in old age, hence taking an inverted U-shape. Financial literacy is also affected by family financial sophistication and literacy level of a neighbourhood. As reported by Lusardi et al. (2010), young people who have financially sophisticated parents that had stocks and retirement savings are likely to know about risk diversification. The role of neighbourhood on financial literacy was highlighted by Lachance (2014) who reported that people living in better-educated neighbourhoods demonstrate higher level of financial literacy revealed through usage of more banking products, saving more for the future, and engaging in less-costly credit activities.

The rest of the paper is organised as follows: Section 2 describes the data and methodology, Section 3 presents the results and discussions and the last section concludes.

\section{Materials and Methods}

\subsection{Data}

Data for the study were obtained from the Financial Inclusion Insight (FII) survey, a nationally representative survey of financial inclusion conducted in 2016 in Kenya and Tanzania. FII is a comprehensive demand-side financial inclusion survey conducted in 10 countries in Africa and Asia. The survey was conducted to measure adoption and use of digital financial services (DFS), track individuals' access to financial services and evaluate service performance among DFS agents and customers. The survey also covers individuals' self-assessment of financial literacy, which is useful in examining such domains of financial literacy as financial knowledge and financial behaviour.

The survey involved 3000 and 3029 adults aged 15 years and older in Kenya and Tanzania, respectively. To achieve a nationally representative sample, the FII survey employed 
a multi-stage sampling approach where the population in each country is segmented into enumerator areas (EAs) that serve as primary sampling units. EAs were randomly selected based on number households. Households within each EA were used as secondary sampling units and respondents were randomly drawn for interview from qualifying household members. The sample data were then weighted back to the population based on age, location (urban/rural) and gender. To ensure data quality, the surveys were implemented using a rigorous quality assurance process during data collection as well as entry.

\subsection{Methodology}

The main aim of our study was to examine the link between financial literacy and financial inclusion in the context of Kenya and Tanzania, lower middle-income economies in East Africa. To this end, first we compared financial literacy in the two countries across socio-economic parameters such as gender, age, religion, location, level of education and livelihoods. To identify determinants of financial literacy, we ran an ordinary least square (OLS) regression model as specified below

$$
F L_{i}=\alpha+\beta x+\varepsilon
$$

where $F L_{i}$ is financial literacy, $X$ is a vector of explanatory variables that include numeracy, age, gender, level of education, marital status, sources of livelihood and location, $\beta$ is the vector of parameters that will be estimated and $\varepsilon$ is the error term. Following the OECD (2017), financial literacy was measured by computing aggregate scores on financial knowledge and financial behaviour. The survey did not include questions to capture financial attitude, the third pillar of financial literacy. Financial knowledge score is calculated based on correct responses to five questions related to inflation and diversification, as well as simple and compound interest (see Appendix A). For financial behaviour, we used six questions on keeping a budget, maintaining an emergency fund, paying bills on time, saving and responsibility for making financial decisions. We computed financial literacy score with values between 0 and 11 by aggregating scores on financial knowledge and financial behaviour. Numeracy was measured based on responses to questions that test respondents' ability in addition and division. We created an aggregated variable with values ranging from 0 to 2 depending on the number of correctly answered questions.

To examine the effect of financial literacy on financial inclusion, we estimated instrumental variable model to address the problem of endogeneity caused by reverse causality, and omitted variable bias and measurement error in capturing financial literacy. We employed the following instrumental variable model

$$
F I_{i}=\alpha+F L_{i}+\beta x+Z x+\varepsilon
$$

where $F I$ is financial inclusion, $F L$ is financial literacy, $X$ is the vector of regressors that include financial literacy, gender, age, age square, location, source of livelihood, religion and level of education, $Z$ is the instrumental variable and is $\varepsilon$ the error term. Financial inclusion is measured based on individuals having access to financial products such as credit, insurance and investment products, as well as holding a bank account and mobile money account. One of the challenges in instrumental variable regression is identifying the right instruments because a wrong instrument can render the output even more biased than OLS (see Fernandes et al. 2014). Guided by previous literature such as Murendo and Mutsonziwa (2017) and based on the nature of our data, we used district level financial literacy and numeracy as instruments for financial literacy. Both variables are correlated with financial literacy, the endogenous variable, without any direct link with financial inclusion, the dependent variable. We introduced numeracy as an instrumental variable after noticing from our OLS estimation a strong link between numeracy and financial literacy. Initially, we introduced district level financial literacy and numeracy separately as instruments for financial literacy but we realized later that they are strong instruments 
when introduced jointly. Our post estimation tests confirmed that the model is fit and instruments are not weak. Wu-Hausman tests confirmed endogeneity of the regressors and the Sargan test confirmed absence of identification errors in the model.

To avoid a dummy variable trap, we estimated four different models per country by introducing one dummy variable at a time. This was done for levels of education and religion due to high degree of multicollinearity confirmed through variance inflation factor (VIF) exceeding the maximum threshold of 10.

\section{Results and Discussion}

As explained in the previous section, first we present a comparison of overall financial literacy score as well as individual dimensions of the construct between the two countries across socio-demographic parameters using mean values. This is followed by an analysis of determinants of financial literacy. The last sub section presents the results of instrumental variable regression where the link between financial literacy and financial inclusion are discussed.

\subsection{Comparison of Financial Literacy between the Two Countries}

Literature shows that financial illiteracy is a problem among particular groups of people (Xu and Zia 2012), and hence we present in this section an analysis of financial literacy along socio-demographic characteristics such as gender, age, location, income, marital status and level of education. As reported in Table 1, comparison of the mean financial literacy score between the two countries shows that the score is higher among adults in Kenya than in Tanzania. A closer look at the two components of financial literacy shows that adults in the two countries differ in terms of financial knowledge and financial behaviour. While Tanzanians exhibit a higher level of financial knowledge than those in Kenya, adults in Kenya excel in terms of financial behaviour. Presented in the ensuing paragraphs are comparison of the overall financial literacy and its components across socio-demographic characteristics.

Table 1. Comparison of key parameters of financial literacy in Kenya and Tanzania (mean values).

\begin{tabular}{|c|c|c|c|c|c|c|}
\hline \multirow[b]{2}{*}{ Variables } & \multicolumn{3}{|c|}{ Kenya } & \multicolumn{3}{|c|}{ Tanzania } \\
\hline & $\begin{array}{c}\text { Financial } \\
\text { Literacy }\end{array}$ & $\begin{array}{c}\text { Financial } \\
\text { Knowledge }\end{array}$ & $\begin{array}{l}\text { Financial } \\
\text { Behaviour }\end{array}$ & $\begin{array}{c}\text { Financial } \\
\text { Literacy }\end{array}$ & $\begin{array}{c}\text { Financial } \\
\text { Knowledge }\end{array}$ & $\begin{array}{l}\text { Financial } \\
\text { Behaviour }\end{array}$ \\
\hline Adult population & 5.208 & 1.777 & 3.431 & 4.379 & 2.215 & 2.164 \\
\hline \multicolumn{7}{|l|}{ Gender } \\
\hline Male & 5.521 & 1.903 & 3.618 & 4.905 & 2.420 & 2.486 \\
\hline Female & 4.985 & 1.687 & 3.297 & 4.029 & 2.079 & 1.950 \\
\hline \multicolumn{7}{|l|}{ Age groups } \\
\hline $15-24$ years & 5.019 & 1.845 & 3.174 & 4.113 & 2.198 & 1.915 \\
\hline $25-34$ years & 5.478 & 1.804 & 3.674 & 4.607 & 2.343 & 2.264 \\
\hline $35-44$ years & 5.361 & 1.846 & 3.515 & 4.446 & 2.239 & 2.207 \\
\hline $45-54$ years & 5.264 & 1.761 & 3.503 & 4.642 & 2.210 & 2.432 \\
\hline 55 and older & 4.766 & 1.442 & 3.324 & 4.041 & 1.900 & 2.141 \\
\hline \multicolumn{7}{|l|}{ Religion } \\
\hline Christian & 5.363 & 1.802 & 3.561 & 4.525 & 2.299 & 2.226 \\
\hline Muslim & 4.003 & 1.568 & 2.435 & 4.167 & 2.096 & 2.071 \\
\hline \multicolumn{7}{|l|}{ Location } \\
\hline Urban & 5.572 & 1.873 & 3.700 & 4.872 & 2.345 & 2.527 \\
\hline Rural & 4.975 & 1.716 & 3.259 & 4.136 & 2.151 & 1.985 \\
\hline \multicolumn{7}{|l|}{ Level of Education } \\
\hline $\begin{array}{l}\text { No formal } \\
\text { education }\end{array}$ & 3.374 & 1.202 & 2.171 & 3.310 & 1.556 & 1.753 \\
\hline Primary school & 4.987 & 1.680 & 3.308 & 4.286 & 2.229 & 2.057 \\
\hline
\end{tabular}


Table 1. Cont.

\begin{tabular}{ccccccc}
\hline \multirow{2}{*}{ Variables } & \multicolumn{3}{c}{ Kenya } & \multicolumn{3}{c}{ Tanzania } \\
\cline { 2 - 7 } & $\begin{array}{c}\text { Financial } \\
\text { Literacy }\end{array}$ & $\begin{array}{c}\text { Financial } \\
\text { Knowledge }\end{array}$ & $\begin{array}{c}\text { Financial } \\
\text { Behaviour }\end{array}$ & $\begin{array}{c}\text { Financial } \\
\text { Literacy }\end{array}$ & $\begin{array}{c}\text { Financial } \\
\text { Knowledge }\end{array}$ & $\begin{array}{c}\text { Financial } \\
\text { Behaviour }\end{array}$ \\
\hline $\begin{array}{c}\text { Secondary } \\
\text { school }\end{array}$ & 5.588 & 1.910 & 3.678 & 5.034 & 2.480 & 2.554 \\
\hline Higher education & 6.459 & 2.256 & 4.204 & 6.971 & 2.986 & 3.986 \\
\hline Livelihood & & & & & & \\
\hline Unemployed & 4.554 & 1.600 & 2.954 & 3.726 & 2.197 & 1.529 \\
\hline Business owner & 5.497 & 1.787 & 3.710 & 4.468 & 2.212 & 2.255 \\
\hline Salaried worker & 6.376 & 2.100 & 4.276 & 6.358 & 2.748 & 3.610 \\
\hline Self-employed & 5.512 & 1.837 & 3.674 & 5.333 & 2.642 & 2.692 \\
\hline $\begin{array}{c}\text { Occasional } \\
\text { worker }\end{array}$ & 5.030 & 1.729 & 3.300 & 4.295 & 2.178 & 2.118 \\
\hline
\end{tabular}

\subsubsection{Gender}

Comparison of financial literacy between males and females shows marked differences along all the three variables. Males in both countries have higher average financial literacy scores than females. Moreover, the average financial literacy score for males is above that of the mean score for the adult population while women have a lower score than the population average. This is also true for financial knowledge and financial behaviour, which might be explained based on low participation of women in the labour market (Bandara 2015) as well as in education in Africa (Piksa 2015).

\subsubsection{Age}

Analysis of financial literacy across age categories shows that, in Kenya, the youth between the ages of 25 and 34 years exhibit the highest financial literacy score while in Tanzania a high financial literacy score is observed among the youth and those in the 45-54 years category. In Kenya, the youth have the highest average financial behaviour score while the highest average financial knowledge score is observed among individuals in the 35-44 years category. In Tanzania, the youth have the highest average score for financial knowledge and while the highest average score for financial behaviour is observed among the $45-54$ years category.

\subsubsection{Religion}

We compared financial literacy levels across religious categories looking at the distribution between Christians and Muslims - the two dominant religions in both countries. Christians in both countries have higher average financial literacy scores than Muslims. They also have a higher financial knowledge and financial behaviour score.

\subsubsection{Location (Urban/Rural)}

Urbanites in both countries exhibit a higher level of average financial literacy than people in rural areas. The average scores for financial knowledge and financial behaviour also show the same trend, which might be due to limited access to information in rural areas as well as a lower level of education. A look at distribution of levels of education shows that while individuals with secondary and higher education are more likely to live in urban areas, those with only primary education or no formal education are more likely to live in rural areas in both countries.

\subsubsection{Education}

Education shows a strong correlation with financial literacy in both countries evidenced by increasing average financial literacy score as one moves from a lower level to a higher level of education. A significant leap in average financial literacy score is observed at two points; the first is between those without formal education and those with a primary 
education. The second leap is observed when one attains a higher education. In Kenya, the average financial behaviour score almost doubles when comparing those without formal education to individuals with a primary education. Such a big leap in the average financial behaviour score is observed in Tanzania only when one moves from secondary education to higher education.

\subsubsection{Livelihoods}

Comparison of financial literacy across sources of livelihoods shows that salaried employees enjoy the highest level of financial literacy both in Kenya and Tanzania. This is driven by the highest average score for financial knowledge and financial behaviour. Business owners and self-employed individuals have comparable average financial literacy scores while the unemployed have the lowest average financial literacy scores.

\subsection{Determinants of Financial Literacy}

We examined the determinants of financial literacy using ordinary least square (OLS) regression. Three models were estimated per country: the first model on overall score of financial literacy, second on financial knowledge and third on financial behaviour.

As reported in Table 2, overall financial literacy in Kenya is strongly explained by numeracy, gender, source of livelihood and location, while coefficients for age and marital status are not statistically significant. Numeracy has a positive and statistically significant $(p<0.01)$ with overall financial literacy score and its components financial knowledge and financial behaviour. Understandably, a higher coefficient of numeracy in the second model suggests that numeracy is more strongly linked with financial knowledge than financial behaviour. This means that lower numeracy skills may not constrain individuals from exercising such behavioural attributes as following a budget, paying bills on time, active saving and involvement in household financial decisions. Females are more likely to be financially illiterate as suggested by a statistically significant negative coefficient. As explained previously, this might be driven by lower participation of women in education and the labour market than men.

Table 2. Determinants of financial literacy in Kenya-OLS results.

\begin{tabular}{|c|c|c|c|}
\hline Variable & $\begin{array}{c}\text { Model 1: } \\
\text { Financial Literacy }\end{array}$ & $\begin{array}{c}\text { Model 2: } \\
\text { Financial Knowledge }\end{array}$ & $\begin{array}{c}\text { Model 3: } \\
\text { Financial Behaviour }\end{array}$ \\
\hline Numeracy & $0.955^{* * *}$ & $1.093^{* * *}$ & $0.483^{* * *}$ \\
\hline Age & -0.001 & $-0.005^{* * *}$ & 0.002 \\
\hline Female & $-0.221^{* * *}$ & $-0.179 * * *$ & $-0.162^{* * *}$ \\
\hline No formal education & ref & ref & ref \\
\hline Primary education & $0.585^{* * *}$ & $0.227 * * *$ & $0.595^{* * *}$ \\
\hline Secondary education & $0.889^{* * *}$ & $0.407^{* * *}$ & $0.864^{* * *}$ \\
\hline Higher education & $1.267 * * *$ & $0.707^{* * *}$ & $1.145^{* * *}$ \\
\hline Single & $-0.184^{* *}$ & 0.088 & $-0.294^{* * *}$ \\
\hline Married & -0.045 & $0.150 *$ & $-0.160^{* *}$ \\
\hline Divorced & -0.027 & 0.037 & -0.059 \\
\hline Unemployed & ref & ref & ref \\
\hline Business owner & $0.066^{* * *}$ & $0.02 * *$ & $0.07^{* * *}$ \\
\hline Irregular worker & $0.059 * * *$ & 0.008 & $0.071^{* * *}$ \\
\hline Salaried worker & $0.056^{* * *}$ & 0.015 & $0.062^{* * *}$ \\
\hline Self-employed & $0.03^{* * *}$ & 0.008 & $0.033^{* * *}$ \\
\hline Rural & $-0.162^{* * *}$ & -0.051 & $-0.173^{* * *}$ \\
\hline Constant & $-1.063^{* * *}$ & $-1.022^{* * *}$ & $-0.67^{* * *}$ \\
\hline
\end{tabular}


Table 2. Cont.

\begin{tabular}{lccc}
\hline Variable & $\begin{array}{c}\text { Model 1: } \\
\text { Financial Literacy }\end{array}$ & $\begin{array}{c}\text { Model 2: } \\
\text { Financial Knowledge }\end{array}$ & $\begin{array}{c}\text { Model 3: } \\
\text { Financial Behaviour }\end{array}$ \\
\hline Adjusted R2 & 0.198 & 0.086 & 0.158 \\
\hline Durbin Watson Stat & 1.92 & 2.009 & 1.888 \\
\hline F-stat & $50.163^{* * *}$ & $19.855^{* * *}$ & $38.387^{* * *}$
\end{tabular}

Note: ${ }^{* * *}$ significant at $1 \%,{ }^{* *}$ significant at $5 \%,{ }^{*}$ significant at $10 \%$. We dropped age square after high degree of multicollinearity was detected.

Level of education is the other important determinant of financial literacy as evidenced by statistically significant positive coefficients. The size of the coefficients increases as one moves from primary education to higher education, suggesting the importance of additional levels of education in improving financial literacy. Interestingly, the difference in the size of the coefficients is larger for financial behaviour than for financial knowledge, implying that education is more strongly related to financial behaviour than financial knowledge. This contrasts with numeracy which exhibits a stronger relation with financial knowledge than financial behaviour.

All livelihood categories are positively related to financial literacy, albeit the coefficients are small in size. A look at the results of financial knowledge and financial behaviour models shows that the positive coefficients are mainly driven by financial behaviour. Financial literacy is biased against individuals living in rural areas as suggested by a statistically significant negative coefficient.

OLS results for Tanzania exhibit a similar trend as that of Kenya. As shown in Table 3, numeracy, gender, education, source of livelihood and location are strongly related to financial literacy.

Table 3. Determinants of financial literacy in Tanzania-OLS results.

\begin{tabular}{|c|c|c|c|}
\hline Variable & $\begin{array}{c}\text { Model 1: } \\
\text { Financial Literacy }\end{array}$ & $\begin{array}{c}\text { Model 2: } \\
\text { Financial Knowledge }\end{array}$ & $\begin{array}{c}\text { Model 3: } \\
\text { Financial Behaviour }\end{array}$ \\
\hline Numeracy & $0.818^{* * *}$ & $1.129^{* * *}$ & $0.227 * *$ \\
\hline Age & 0.001 & -0.003 & $0.003^{* *}$ \\
\hline Female & $-0.317^{* * *}$ & $-0.218^{* * *}$ & $-0.271^{* * *}$ \\
\hline No formal education & ref & ref & ref \\
\hline Primary education & $0.234^{* * *}$ & $0.247 * * *$ & $0.128 * *$ \\
\hline Secondary education & $0.507^{* * *}$ & $0.385^{* * *}$ & $0.403^{* * *}$ \\
\hline Higher education & $1.197^{* * *}$ & $0.733^{* * *}$ & $1.098 * * *$ \\
\hline Single & $-0.182 * *$ & -0.034 & $-0.232^{* *}$ \\
\hline Married & -0.058 & 0.073 & -0.143 \\
\hline Divorced & 0.114 & 0.052 & 0.119 \\
\hline Unemployed & ref & ref & ref \\
\hline Business owner & $0.034^{* * *}$ & $0.022 * *$ & $0.031^{* * *}$ \\
\hline Irregular worker & $0.067 * * *$ & $0.033^{* *}$ & $0.067^{* * *}$ \\
\hline Salaried worker & $0.086^{* * *}$ & 0.036 ** & $0.094^{* * *}$ \\
\hline Self-employed & $0.044^{* * *}$ & $0.036^{* * *}$ & $0.033^{* * *}$ \\
\hline Rural & $-0.237^{* * *}$ & -0.059 & $-0.290 * * *$ \\
\hline Constant & -0.210 & $-0.915^{* * *}$ & $0.462 * *$ \\
\hline Adjusted R2 & 0.187 & 0.121 & 0.158 \\
\hline Durbin Watson Stat & 1.867 & 1.865 & 1.889 \\
\hline F-stat & $46.763^{* * *}$ & $28.424^{* * *}$ & $38.357^{* * *}$ \\
\hline
\end{tabular}

Note: ${ }^{* * *}$ significant at $1 \%,{ }^{* *}$ significant at $5 \%$. We dropped age square after high degree of multicollinearity was detected. 


\subsection{The Link between Financial Literacy and Financial Inclusion: IV Regression Analysis}

We estimated instrumental variable models in Stata using ivregress command experimenting with different models by introducing different sets of control variable at a time. However, we reported results only for models that passed our post estimation tests. As reported in Tables 4 and 5, all four models that we implemented per country show a statistically significant $(p<0.01)$ positive effect of financial literacy on financial inclusion. This suggests that financial knowledge and behaviour is a good predictor of individuals choice to hold a financial product or access a service. This has implication for the expansion of financial inclusion because the availability of financial products and services does not automatically lead to an increase in financial inclusion unless individuals understand the value of such products in managing their financial lives.

Table 4. Financial literacy and financial inclusion in Kenya: IV regression results.

\begin{tabular}{|c|c|c|c|c|}
\hline Variable & Model 1 & Model 2 & Model 3 & Model 4 \\
\hline Financial literacy & $0.388072^{* * *}$ & $0.3952424^{* * *}$ & $0.4322061^{* * *}$ & $0.403814^{* * *}$ \\
\hline Gender & -0.0208876 & -0.0148675 & -0.015899 & -0.0266861 \\
\hline Age & $0.0849172 * * *$ & $0.0844878^{* * *}$ & $0.0870644^{* * *}$ & $0.0877045^{* * *}$ \\
\hline Age square & $-0.0008113^{* * *}$ & $-0.0008059^{* * *}$ & $-0.0008344^{* * *}$ & $-0.0008426^{* * *}$ \\
\hline Rural & $-0.1655875^{* * *}$ & $-0.1649211^{* * *}$ & $-0.1644355^{* * *}$ & $-0.1740197^{* * *}$ \\
\hline Unemployed & Ref & Ref & Ref & Ref \\
\hline Business owner & $0.068005^{* * *}$ & $0.0681678^{* * *}$ & $0.0645443^{* * *}$ & $0.0612814^{* * *}$ \\
\hline Salaried worker & $0.0550054^{* * *}$ & $0.0550758^{* * *}$ & $0.0741108^{* * *}$ & $0.0814998^{* * *}$ \\
\hline Self-employed & $0.0448188^{* * *}$ & $0.0451312^{* * *}$ & $0.0418289^{* * *}$ & $0.0400832^{* * *}$ \\
\hline Occassional worker & -0.0014356 & -0.0011861 & -0.0021159 & -0.005352 \\
\hline Christian & $0.2324526^{* * *}$ & & $0.2482078^{* * *}$ & $0.2472563 * * *$ \\
\hline Muslim & & $-0.2148005^{* * *}$ & & \\
\hline Primary education & & & $-0.1621397^{* * *}$ & \\
\hline $\begin{array}{l}\text { Secondary } \\
\text { education }\end{array}$ & & & & $0.0963235^{* * *}$ \\
\hline Higher education & $0.6226608^{* * *}$ & $0.6233158^{* * *}$ & & \\
\hline Constant & $-1.872975^{* * *}$ & $-1.649629 * * *$ & $-1.811014^{* * *}$ & $-1.890561^{* * *}$ \\
\hline Wu-Hausman $\mathrm{F}^{+}$ & $8.78824^{* * *}$ & $9.68896^{* * *}$ & $14.2975^{* * *}$ & $7.8783^{* * *}$ \\
\hline F-stat $^{++}$ & $269.505^{* * *}$ & $268.056^{* * *}$ & $290.173^{* * *}$ & $267.565^{* * *}$ \\
\hline Sargan Chi2 ${ }^{+++}$ & 5.27943 & 5.70806 & 7.8275 & 4.918 \\
\hline
\end{tabular}


Table 5. Financial literacy and financial inclusion in Tanzania: IV regression results.

\begin{tabular}{|c|c|c|c|c|}
\hline Variable & Model 1 & Model 2 & Model 3 & Model 4 \\
\hline Financial literacy & $0.152502 * * *$ & $0.1593784^{* * *}$ & $0.1772662 * * *$ & $0.1740959 * * *$ \\
\hline Gender & $-0.07964^{* *}$ & $-0.07702 * *$ & $-0.08173^{* *}$ & -0.0725533 * \\
\hline Age & $0.0441911^{* * *}$ & $0.0438847^{* * *}$ & $0.0447138^{* * *}$ & $0.0461492 * * *$ \\
\hline Age square & $-0.0004532 * * *$ & $-0.0004499^{* * *}$ & $-0.0004588^{* * *}$ & $-0.0004675^{* * *}$ \\
\hline Rural & $-0.1645393^{* * *}$ & $-0.1596221^{* * *}$ & $-0.1678244^{* * *}$ & $-0.1578423^{* * *}$ \\
\hline Unemployed & Ref & Ref & Ref & Ref \\
\hline Business owner & 0.0149484 & 0.0142693 & 0.0086716 & 0.0097663 \\
\hline Salaried worker & $0.0896657^{* * *}$ & $0.0890638^{* * *}$ & $0.1154946^{* * *}$ & $0.1148463^{* * *}$ \\
\hline Self-employed & 0.0008621 & 0.0006838 & -0.0044424 & -0.0053281 \\
\hline Occassional worker & $-0.0251417^{* * *}$ & $-0.0253457^{* * *}$ & $-0.0292008^{* * *}$ & $-0.028187^{* * *}$ \\
\hline Christian & 0.0471929 & & 0.0530793 & 0.0512697 \\
\hline Muslim & & -0.0163076 & & \\
\hline Primary education & & & -0.0515873 & \\
\hline $\begin{array}{l}\text { Secondary } \\
\text { education }\end{array}$ & & & & $0.1295293^{* * *}$ \\
\hline Higher education & $1.145899 * * *$ & $1.143133^{* * *}$ & & \\
\hline Constant & $-0.5128022^{* * *}$ & $-0.4820504^{* * *}$ & $-0.4442476^{* * *}$ & $-0.5744217^{* * *}$ \\
\hline Wu-Hausman $\mathrm{F}^{\dagger}$ & $7.39447^{* * *}$ & $6.79689 * * *$ & $6.86565^{* * *}$ & $6.74697^{* * *}$ \\
\hline F-stat ${ }^{\dagger+}$ & $232.822^{* * *}$ & $234.939 * * *$ & $236.492 * * *$ & $235.661^{* * *}$ \\
\hline Sargan Chi2 ${ }^{+++}$ & 3.98586 & 3.6742 & 4.60469 & 4.17937 \\
\hline
\end{tabular}

Note: ${ }^{* * *}$ significant at $1 \%$ level, ${ }^{* *}$ significant at $5 \%$ level, ${ }^{*}$ significant at $10 \%$ level. ${ }^{+}$test of endogeneity against a null hypothesis that variables are exogenous. ${ }^{+\dagger}$ test of instruments against the null hypothesis that instruments are weak. ${ }^{++t}$ test of overidentifying restrictions.

Our results reveal interesting facts about the control variables. In Kenya, financial inclusion of individuals is not determined by their gender which is contrary to previous literature that reports a significant number of women in developing countries are financially excluded (see Demirguc-Kunt et al. 2013; Klapper and Singh 2015). It is worth noting that Kenya, being at the forefront of the development of digital financial services particularly mobile money services in Africa, has significantly narrowed the gender gap in financial inclusion. This has been confirmed by the fact that the gender gap among the banked is $15 \%$ but it is only $7 \%$ for those with a mobile money account. The financial inclusion gap decreases significantly as we add other products such as insurance, credit and investment. In contrast, the Tanzanian model reported in Table 5 shows that gender has a statistically significant $(p<0.05)$ negative effect on financial inclusion, suggesting that Tanzanian women are more likely to be financially excluded than men.

Age has an inverted $U$-shaped relationship with financial inclusion as suggested by a positive coefficient for the main variable and negative coefficient for age square. This implies that financial inclusion increases with age up to a point and declines afterwards, which is intuitively correct. Financial inclusion is low during early years due to individuals not have enough financial resources to need financial services and inclusion increases thereafter until it reaches its maximum level before retirement. Consumption of financial services declines once individuals attain a retirement age. For instance, the retired may not seek credit and insurance products due to lack of financial ability to access them. Similarly, the need for financial products and services of young adults may be limited to a bank account until they have a reliable source of livelihood.

A negative and statistically significant coefficient for rural suggests that individuals living in rural areas are less likely to be financially included; this is consistent with the 
literature (see Allen et al. 2016; World Bank 2020) that reports financial inclusion is biased against individuals living in rural areas. Low levels of financial inclusion in rural areas might be driven by both supply side and demand side factors. From the supply side, financial institutions are not widely present in rural areas and from the demand side uptake of financial products is low due to lack of adequate understanding of their benefits.

For sources of livelihoods, all categories except occasional workers are likely to be financially included in Kenya. The coefficient for occasional worker is negative and statistically insignificant $(p>0.10)$ suggesting that this category is not linked to financial inclusion. In contrast, in the Tanzanian models only the coefficient for salaried workers is positive is statistically significant $(p<0.01)$ while the coefficient for occasional workers is negative and statistically significant $(p<0.01)$. Business owners and the self-employed are more likely to be financially included in Kenya but insignificant coefficients for both suggest that they are not important predictors of financial inclusion in the Tanzanian context.

Our results suggest that in Kenya Christians are more likely to be financially included while Muslims are less likely to be included. In Tanzania, however, religion is not related to financial inclusion. Education is the other important predictor of financial inclusion in both countries, with individuals who have a secondary education and above exhibiting a higher likelihood of being financially included. In contrast, those with only primary education are likely to have a lower level of financial inclusion as suggested by a negative and statistically significant coefficient.

In general, our results confirm a strong link between financial inclusion and financial literacy in Kenya and Tanzania. Our analysis of the control variables shows that age, location, religion, source of livelihood and level of education drive financial inclusion in Kenya. In Tanzania, gender, age, location, source of livelihood and education explain differences in financial inclusion among the adult population in the country.

\section{Conclusions}

Having recognized its welfare enhancing effects, policy makers in developing countries are advocating for expansion of financial inclusion. Efforts are being exerted in many countries to boost financial inclusion by increasing individuals' access to financial products and services. We, however, argue that the drive to increase financial inclusion by focusing on the supply-side factors alone may not be successful unless efforts are exerted in enhancing financial literacy to ensure individuals understand the range of financial products available in the market and make rational choices in shopping for products and services that suits their specific needs.

We examined the link between financial literacy and financial inclusion using FII surveys conducted in two East African economies, i.e., Kenya and Tanzania. We measured financial literacy using two dimensions, namely, financial knowledge and financial behaviour. To address potential bias in our results caused by endogeneity, we executed instrumental variable regression. Consistent with expectation, our result confirmed that financial literacy is strongly linked to increased level of financial inclusion. This implies that efforts to increase financial inclusion need to be accompanied with financial literacy campaigns.

Author Contributions: A.F., Conceptualization, methodology, software, validation, formal analysis, writing—original draft preparation; K.M., Conceptualization and writing-review and editing. All authors have read and agreed to the published version of the manuscript.

Funding: This research received no external funding.

Data Availability Statement: Datasets used in this paper were accessed from Intermedia and they are available for academic purpose.

Acknowledgments: We are grateful for valuable comments from anonymous reviewers on earlier versions of the paper.

Conflicts of Interest: The authors declare no conflict of interest. 


\section{Appendix A}

Table A1. Measurement of numeracy, financial literacy and financial inclusion.

\begin{tabular}{|c|c|c|}
\hline Variable & Survey Question & Coding \\
\hline 1. Numeracy & $(a)+(b)$ & Value ranges between 0 and 2 \\
\hline (a) Addition & $\begin{array}{l}\text { Imagine you have } 1000 \mathrm{KSH} \text {. } \\
\text { Somebody gave you } 200 \mathrm{KSH} \text {. } \\
\text { How much total money will you } \\
\text { have? ( } 1=1200 \mathrm{KSH} ; 2=\text { any } \\
\text { other answer; } 99=\mathrm{DK})\end{array}$ & $\begin{array}{l}1=(1) \text { Correct answer } \\
0=\text { Any other answer } / \mathrm{DK}\end{array}$ \\
\hline (b) Division & $\begin{array}{l}\text { Imagine you have } 100 \mathrm{KSH} \text { and } \\
\text { you have to divide it among } \\
5 \text { people. How much money will } \\
\text { each person receive if you divide } \\
\text { it equally? }(1=20 \mathrm{KSH} ; 2=\text { any } \\
\text { other answer; } 99=\mathrm{DK} \text { ) }\end{array}$ & $\begin{array}{l}1=(1) \text { Correct answer } \\
0=\text { Any other answer } / \mathrm{DK}\end{array}$ \\
\hline
\end{tabular}

\begin{tabular}{ll}
\hline 2. Financial literacy & $(\mathrm{a})+(\mathrm{b})$ \\
\hline (a) Financial knowledge & $\mathrm{i}+\mathrm{ii}+\mathrm{iii}+\mathrm{iv}+\mathrm{v}$
\end{tabular}

\begin{tabular}{ll} 
(a) Financial knowledge & $\mathrm{i}+\mathrm{ii}+\mathrm{iii}+\mathrm{iv}+\mathrm{v}$ \\
\hline & Suppose you have some money.
\end{tabular} Is it safer to put your money into one business or investment, or to

(i) Diversification

businesses or investments?
$(1=$ one business/investment; 2 = Multiple businesses/investments; $99=\mathrm{DK})$

Suppose over the next 10 years the prices of the things you buy double. If your income also doubles, will you be able to buy

(ii) Inflation less than you can buy today, the same as you can buy today, or more than you can buy today? $(1=$ Less; 2 = the same; $3=$ More; $99=\mathrm{DK})$

Suppose you need to borrow $100 \mathrm{KSH}$. Which is the lower amount to pay back: $105 \mathrm{KSH}$ or $100 \mathrm{KSH}$ plus 3 percent? $(1=105$ $\mathrm{KSH} ; 2=100 \mathrm{KSH}+3 \%$; $99=\mathrm{DK})$
$1=(2)$ Correct answer

$0=$ Less (1), More (3), DK (99)
$1=(2)$ Correct answer

$0=$ one business $/$ investment

(1), DK (99)
Suppose you put money in the bank for two years and the bank agrees to add 15 percent per year to your account. Will the bank add more money to your account the second year than it did the first year, or will it add the same $1=(2) 100 \mathrm{KSH}$ plus 3\%

$0=105 \mathrm{KSH}$ (1), DK (99) amount of money both years? ( 1 = Less; 2 = the same; 3 = More; $99=$ DK) 
Table A1. Cont.

\begin{tabular}{lll}
\hline Variable & Survey Question & Coding \\
\hline & Suppose you had 100 KSH. in \\
& a savings account and the \\
& bank adds 10 percent per year \\
& to the account. How much & \\
& money would you have in the $\quad 1=(1)$ correct answer \\
& account after five years if you $\quad 0=$ exactly 150 KSH (2), Less \\
& did not remove any money $\quad$ than 150 KSH (3); DK (99) \\
& from the account? (1= More \\
& than 150 KSH; 2 = Exactly 150 \\
& KSH; 3 = Less than 150 KSH; \\
& $99=$ DK) \\
\hline
\end{tabular}

(b) Financial behavior
(i) Frequency of financial
planning

$\mathrm{i}+\mathrm{ii}+\mathrm{iii}+\mathrm{iv}+\mathrm{v}+\mathrm{vi}$

How often do you make a plan for how to spend your income, whether it is earned through a job, received from the government or from other

$1=1$ and 2 planning people? Always = 1,

Sometimes $=2$, Rarely $=3$, Never $=4$

When you make a plan, how

(ii) Budget often do you keep it?
Always $=1$, Sometime Always = 1, Sometimes $=2$, Rarely $=3$, Never $=4$

(iii) Role in financial decision Who usually decides how the $1=$ Myself (1) money you earn will be used? $0=$ Others

(iv) Keep emergency funds

(v) Pay bills on time

(vi) Active saving

\section{Financial inclusion}

(a) Credit

\section{(b) Insurance}

(c) Investment

(d) Bank account

$\begin{array}{ll}\begin{array}{ll}\text { I have an emergency fund to } \\ \text { cover unplanned expenses }\end{array} & \begin{array}{l}1=\text { Yes } \\ 0=\text { No }\end{array} \\ \begin{array}{ll}\text { Tell me, does the following } \\ \text { apply to you? I pay my bills } \\ \text { on time }\end{array} & \begin{array}{l}1=\text { Yes } \\ 0=\text { No }\end{array} \\ \begin{array}{ll}\text { Do you save with any of the } \\ \text { following? }\end{array} & \begin{array}{l}1=\text { Yes } \\ 0\end{array}=\text { No }\end{array}$
$\mathrm{a}+\mathrm{b}+\mathrm{c}+\mathrm{d}+\mathrm{e}$

Have you borrowed money/have loans from the $1=$ Yes following organizations or $\quad 0=\mathrm{No}$ individuals? Bank, personal

$1=1$ and 2

$0=3$ and 4 or business loans?

Do you have the following $1=$ Yes
insurance? $0=\mathrm{No}$

Do you invest in any of the $1=$ Yes

following? $\quad 0=\mathrm{No}$

$\begin{array}{ll}\text { Do you personally have a } & \\ \text { bank account that is registered } & \begin{array}{l}1=\text { Yes } \\ 0\end{array} \\ & \text { No }\end{array}$
in your name?

Do you have a registered account (account registered in $1=$ Yes your name) with this mobile $\quad 0=$ No money service?

Note: FII surveys are standardized and, as a result, similar questions are used in soliciting financial knowledge and behavior of individuals in Kenya and Tanzania. Questions on numeracy and interest rate differ only with respect to the currency and amounts. 


\section{References}

Acquah-Sam, Emmanuel, and King Salami. 2013. Knowledge and participation in capital market activities: The Ghanaian Experience. International Journal of Scientific Research in Education 6: 189-203.

Allen, Franklin, Asli Demirguc-Kunt, Leora Klapper, and Maria Soledad Martinez Peria. 2016. The foundations of financial inclusion: Understanding ownership and use of formal accounts. Journal of Financial Intermediation 27: 1-30. [CrossRef]

Bandara, Amarakoon. 2015. The economic cost of gender gaps in effective labor: Africa's missing growth reserve. Feminist Economics 21: 162-86. [CrossRef]

Burke, Mary A., and Michael Manz. 2014. Economic literacy and inflation expectations: Evidence from a laboratory experiment. Journal of Money, Credit and Banking 46: 1421-56. [CrossRef]

Calcagno, Riccardo, and Chiara Monticone. 2015. Financial literacy and the demand for financial advice. Journal of Banking $\mathcal{E}$ Finance 50: 363-80.

Cole, Shawn, Thomas Sampson, and Bilal Zia. 2011. Prices or knowledge? What drives demand for financial services in emerging markets? The Journal of Finance 66: 1933-67. [CrossRef]

Dahmen, Pearl, and Eileen Rodríguez. 2014. Financial literacy and the success of small businesses: An observation from a small business development centre. Numeracy 7: 3. [CrossRef]

Demirguc-Kunt, Asli, Leora Klapper, and Dorothe Singer. 2013. The Global Findex Database: Women and Financial Inclusion. Findex Note Number 09. Washington, DC: The World Bank Group.

Disney, Richard, and John Gathergood. 2011. Financial Literacy and Indebtedness: New Evidence for UK Consumers. Nottingham: The University of Nottingham.

Fernandes, Daniel, John G. Lynch Jr., and Richard G. Netemeyer. 2014. Financial literacy, financial education, and downstream financial behaviors. Management Science 60: 1861-83. [CrossRef]

Finke, Michael S., John S. Howe, and Sandra J. Huston. 2016. Old age and the decline in financial literacy. Management Science 63: 213-30. [CrossRef]

Jappelli, Tulio, and Mario Padula. 2013. Investment in financial literacy and saving decisions. Journal of Banking E Finance 37: 2779-92.

Klapper, Leora, and Sandeep Singh. 2015. The Gender Gap in the Use of Financial Services in Turkey. Washington, DC: The World Bank.

Klapper, Leora, Annamaria Lusardi, and Georgios A. Panos. 2013. Financial literacy and its consequences: Evidence from Russia during the financial crisis. Journal of Banking E Finance 37: 3904-23.

Klapper, Leora F., Annamaria Lusardi, and Peter van Oudheusden. 2015. Financial Literacy around the World: Insights from the Standard \& Poor's Ratings Services Global Financial Literacy Survey. S\&P International. Available online: http:/ / media.mhfi. com/documents/2015-Finlit_paper_17_F3_SINGLES.pdf (accessed on 21 July 2016).

Lachance, Marie Eve. 2014. Financial literacy and neighbourhood effects. Journal of Consumer Affairs 48: 251-73. [CrossRef]

Lührmann, Melanie, Marta Serra-Garcia, and Joachim Winter. 2015. Teaching teenagers in finance: Does it work? Journal of Banking $\mathcal{E}$ Finance 54: 160-74.

Lusardi, Annamaria, and Olivia S. Mitchell. 2011. Financial literacy around the world: An overview. Journal of Pension Economics and Finance 10: 497-508. [CrossRef] [PubMed]

Lusardi, Annamaria, and Peter Tufano. 2015. Debt literacy, financial experiences, and overindebtedness. Journal of Pension Economics and Finance 14: 332-68. [CrossRef]

Lusardi, Annamaria, Olivia S. Mitchell, and Vilsa Curto. 2010. Financial literacy among the young. Journal of Consumer Affairs 44: 358-80. [CrossRef]

Murendo, Conrad, and Kingstone Mutsonziwa. 2017. Financial literacy and savings decisions by adult financial consumers in Zimbabwe. International Journal of Consumer Studies 41: 95-103. [CrossRef]

OECD. 2017. G20/OECD INFE Report on Adult Financial Literacy in G20 Countries. Available online: https://www.oecd.org/daf/ fin/ financial-education/G20-OECD-INFE-report-adult-financial-literacy-in-G20-countries.pdf (accessed on 22 June 2021).

OECD-INFE. 2012. High-Level Principles on National Strategies for Financial Education. Paris: Organization for Economic Cooperation and Development.

Piksa, Marta. 2015. EFA Global Monitoring Report, Gender and EFA 2000-2015: Achievements and Challenges. Paris: United Nations Educational Scientific and Cultural Organization, p. 50.

Silgoner, Maria Antoinette, Bettina Greimel-Fuhrmann, and Rosa Weber. 2015. Financial literacy gaps of the Austrian population. Monetary Policy \& the Economy Q2: 35-51.

Von Gaudecker, Hans Martin. 2015. How does household portfolio diversification vary with financial literacy and financial advice? The Journal of Finance 70: 489-507. [CrossRef]

World Bank. 2020. The World Bank Annual Report 2020: Supporting Countries in Unprecedented Times. Washington, DC: World Bank. Available online: https:/ / openknowledge.worldbank.org/handle/10986/34406 (accessed on 21 May 2021).

$\mathrm{Xu}$, Lisa, and Bilal Zia. 2012. Financial Literacy around the World: An Overview of the Evidence with Practical Suggestions for the Way Forward. World Bank Policy Research Working Paper (6107). Washington, DC: World Bank. 